\title{
The impact of Sosnowsky's Hogweed on feeding guilds of birds
}

\author{
Emilia Grzędzicka' ${ }^{1}$ - Jiří Reif ${ }^{2,3}$ (B)
}

Received: 15 September 2020 / Revised: 8 February 2021 / Accepted: 14 May 2021 / Published online: 26 May 2021

(c) The Author(s) 2021

\begin{abstract}
Plant invasions alter bird community composition worldwide, but the underlying mechanisms still require exploration. The investigation of feeding guild structure of bird communities can be informative in respect to the potential impact of invasion features on the availability of food for birds. For this purpose, we focused on determining the influence of the invasive Sosnowsky's Hogweed Heracleum sosnowskyi on the abundance of birds from various feeding guilds. In spring and summer 2019, birds were counted three times on 52 pairs of sites (control + Heracleum) in southern Poland, at various stages of Sosnowsky's Hogweed development (i.e. sprouting, full growth and flowering, all corresponding to respective bird counts). We have shown that the presence of invader negatively affected the abundance of birds from all feeding guilds. However, a closer examination of the invaded sites uncovered that responses of particular guilds differed in respect to development stages expressed by a set of characteristics of the invader. Ground and herb insectivores were more common on plots with a higher number of the invader, while the abundance of bush and tree insectivores was negatively correlated with hogweeds' height. Granivores were not affected by the invader's features, while the abundance of omnivores was negatively related to the number of flowering hogweeds. Besides showing the general negative impact of the invader on different feeding guilds, our research has shown that certain aspects of Sosnowsky's Hogweed invasion may support or depress occurrence of different birds on invaded plots. Knowledge of these aspects may facilitate our capacity for coping with challenges the invasive plants put in front of bird conservationists.
\end{abstract}

Keywords Heracleum sosnowskyi · Food resources · Insectivores · Granivores · Omnivores · Invasion development stages · Flowering

Communicated by T. Gottschalk.

Emilia Grzędzicka

grzedzicka@isez.pan.krakow.pl

$\triangle$ Jiří Reif

jirireif@natur.cuni.cz

1 Institute of Systematics and Evolution of Animals, Polish Academy of Sciences, Sławkowska 17, 31-016 Kraków, Poland

2 Institute for Environmental Studies, Faculty of Science, Charles University in Prague, Benatska 2, 12801 Praha 2, Czech Republic

3 Department of Zoology and Laboratory of Ornithology, Faculty of Science, Palacky University in Olomouc, 17. listopadu 50, 77146 Olomouc, Czech Republic 


\section{Zusammenfassung}

\section{Auswirkungen von Sosnowsky-Bärenklau auf Nahrungsgilden bei Vögeln}

Das Vordringen invasiver Pflanzen verändert weltweit die Zusammensetzung von Vogelgemeinschaften; die Mechanismen, welche dem zugrundeliegen, harren aber immer noch der Aufklärung. Eine Untersuchung der Struktur von Nahrungsgilden bei Vogelgemeinschaften kann Informationen bezüglich der potenziellen Auswirkungen des Invasionsgeschehens auf die Verfügbarkeit von Nahrung für die Vögel liefern. Zu diesem Zweck konzentrierten wir uns darauf, den Einfluss des invasiven Sosnowsky-Bärenklaus Heracleum sosnowskyi auf die Häufigkeit von Vogelarten aus verschiedenen Nahrungsgilden zu bestimmen. Im Frühjahr und Sommer 2019 wurden die Vögel dreimal, jeweils zu verschiedenen Entwicklungsstadien des Sosnowsky-Bärenklaus (d. h. sprießend, ausgewachsen und blühend), auf 52 Flächenpaaren (Kontrollfläche und Heracleum-Fläche) in Südpolen gezählt. Wir konnten zeigen, dass die Anwesenheit des pflanzlichen Eindringlings die Häufigkeit von Vögeln aller Nahrungsgilden negativ beeinflusste. Eine nähere Untersuchung der befallenen Flächen enthüllte allerdings, dass sich die Reaktionen bestimmter Gilden im Hinblick auf die durch eine Reihe von Merkmalen definierten Entwicklungsstadien des invasiven Neophyten unterschieden. Bodenbewohnende Insektenfresser kamen auf Flächen mit einer höheren Anzahl Neophyten häufiger vor, wohingegen die Häufigkeit busch- und baumbewohnender Insektenfresser in negativem Zusammenhang mit der Höhe der Bärenklau-Pflanzen stand. Körnerfresser wurden durch die Eigenschaften des invasiven Neophyten nicht beeinflusst, während die Häufigkeit von Omnivoren in negativer Beziehung zur Anzahl blühender Bärenklaue stand. Abgesehen von den generell negativen Auswirkungen des pflanzlichen Eindringlings auf die verschiedenen Nahrungsgilden zeigte unsere Studie, dass bestimmte Aspekte einer Sosnowsky-Bärenklau-Invasion das Auftreten verschiedener Vogelarten auf den befallenen Flächen fördern oder verringern können. Die Kenntnis dieser Zusammenhänge könnte es uns leichter machen, mit den Herausforderungen fertigzuwerden, vor die invasive Pflanzenarten den Naturschutz stellen.

\section{Introduction}

The spread of invasive species is one of the most important global environmental problems (McGowan et al. 2017) which changes the structure and functioning of bird communities (Castro-Díez and Alonso 2017). Pathway by which invasive plants can affect birds is changing their food resources (Nelson et al. 2017; Doizy et al. 2018). The negative responses of birds to plant invasions are usually linked to their specialization to certain food resources (Grass et al. 2013) and deterioration of the birds' food base (Skórka et al. 2010; Narango et al. 2018). For example, alien plants may become physical barriers for aerial insects (Aravind et al. 2010) and invasive plants forming dense thickets may lower access of insectivorous birds to arthropods (Osborne et al. 2012). Plant invasion can also affect arthropods selectively according to their ecology (Hejda et al. 2017; Strobl et al. 2019) or reduce the biomass of arthropods that require native plants as food (Litt et al. 2014).

Alternatively, when invasive plants increase vegetation patchiness, foraging opportunities for insectivores may improve as the visibility of arthropods increases (Walker 2008). Plant invasion may also positively influence the native arthropod community (Dudek et al. 2016). The positive effects of alien plants are particularly common in frugivores, because fleshy-fruited invasive species may become important resources for frugivorous birds whose native food resources declined (Foster and Robinson 2007), are less valuable than aliens (Bourgeois et al. 2005; Vila and D'Antonio
1998) or temporarily unavailable (Corlett 2005). In contrast to such frequently documented positive effects of invasion on fruit-eating birds, some non-fleshy-fruit invasive plants are known to attract insects, but no one has studied their effects on birds. Investigation of the use of exotic plants as food resources for birds can be performed by comparison of different feeding guilds foraging near invaders that are remarkable in some way (e.g. huge size of the plant, with big inflorescences producing numerous seeds). In this work, we focus on an alien flowering weed species, Sosnowsky's Hogweed Heracleum sosnowskyi, for this purpose.

Sosnowsky's Hogweed comes from the eastern and central Caucasus; central, eastern and south-western Transcaucasia and north-eastern Anatolia in Turkey (Moravcová et al. 2007). This plant invader combines many features that can be expected to affect various feeding guilds of birds. First, its leaves are especially large, dense and fast-growing (Bogdanov et al. 2016) providing huge biomass potentially useful for many different arthropods, although it also may limit the space for arthropods that need native plants. Second, based on reproductive potential studied on different invasive Caucasian hogweeds, one plant may produce 5-50 thousand seeds per year (Orlov et al. 1990; Perglová et al. 2007), which can germinate for 5-6 years (Orlov et al. 1990). These seeds are extremely abundant in upper soil layers (Moravcová et al. 2007; Dalke et al. 2015) and easily accessible for granivorous and omnivorous birds (although it was not studied whether birds use those seeds). On the other hand, it can also lead to habitat monopolization and impoverishment 
of the environment potentially used by foraging birds. Third, invasive hogweeds are attractive to numerous insects. For example, about 162 species of insects were recorded on the leaf surface, stem and umbel of Giant Hogweed H. mantegazzianum, of which 123 were polyphagous generalists, while the number of insect specialists was lower (Hansen et al. 2006). It is also known that the flowers of Sosnowsky's Hogweed, which is closely related to Giant Hogweed, attract a variety of pollinators, including Hymenoptera, Diptera, Coleoptera, and Hemiptera (Grace and Nelson 1981; Satsyperova 1984).

Considering all the above-mentioned characteristics of Sosnowsky's Hogweed (i.e. large green area, the attractiveness of leaves and flowers for various arthropods, habitat monopolization and high seed productivity with unknown impact on birds), both an increase in the availability of food base for birds, as well as its significant impoverishment, are possible outcomes of the occurrence of this invader. To elucidate these possibilities, we related the occurrence of Sosnowsky's Hogweed to the number of birds classified as insectivores, granivores or omnivores, as these guilds may show different responses to the presence of the invader. In the case of insectivores, we classified birds to ground/herb and bush/tree insectivores to take into account the birds' typical foraging stratum in the context of hogweed development. We considered the impact of development stages of the invader using a set of its local characteristics (number, cover, height, number of flowering hogweeds) on all four guilds of birds. Our study aims to test the following hypotheses:

1. The occurrence of Sosnowsky's Hogweed negatively impacts the abundance of ground/herb and bush/tree insectivores. However, different hogweed characteristics are differently related to the abundance of birds from these two guilds according to their foraging strata. Lower cover (and thus higher patchiness) of hogweeds supports the abundance of ground/herb insectivores as it facilitates the visibility of insects (Walker 2008), although high number of hogweeds may be also beneficial for the insect availability. In contrast, numerous hogweeds forming dense vegetation lowering insect accessibility (Osborne et al. 2012) are detrimental for ground/ herb insectivorous birds, while bush/tree insectivores are negatively affected by tall and flowering hogweeds appearing in space used by these birds as they become physical barriers for aerial insects (Aravind et al. 2010).

2. Sosnowsky's Hogweed number positively affects the abundance of granivores and omnivores due to the easy access of numerous and potentially attractive seeds.

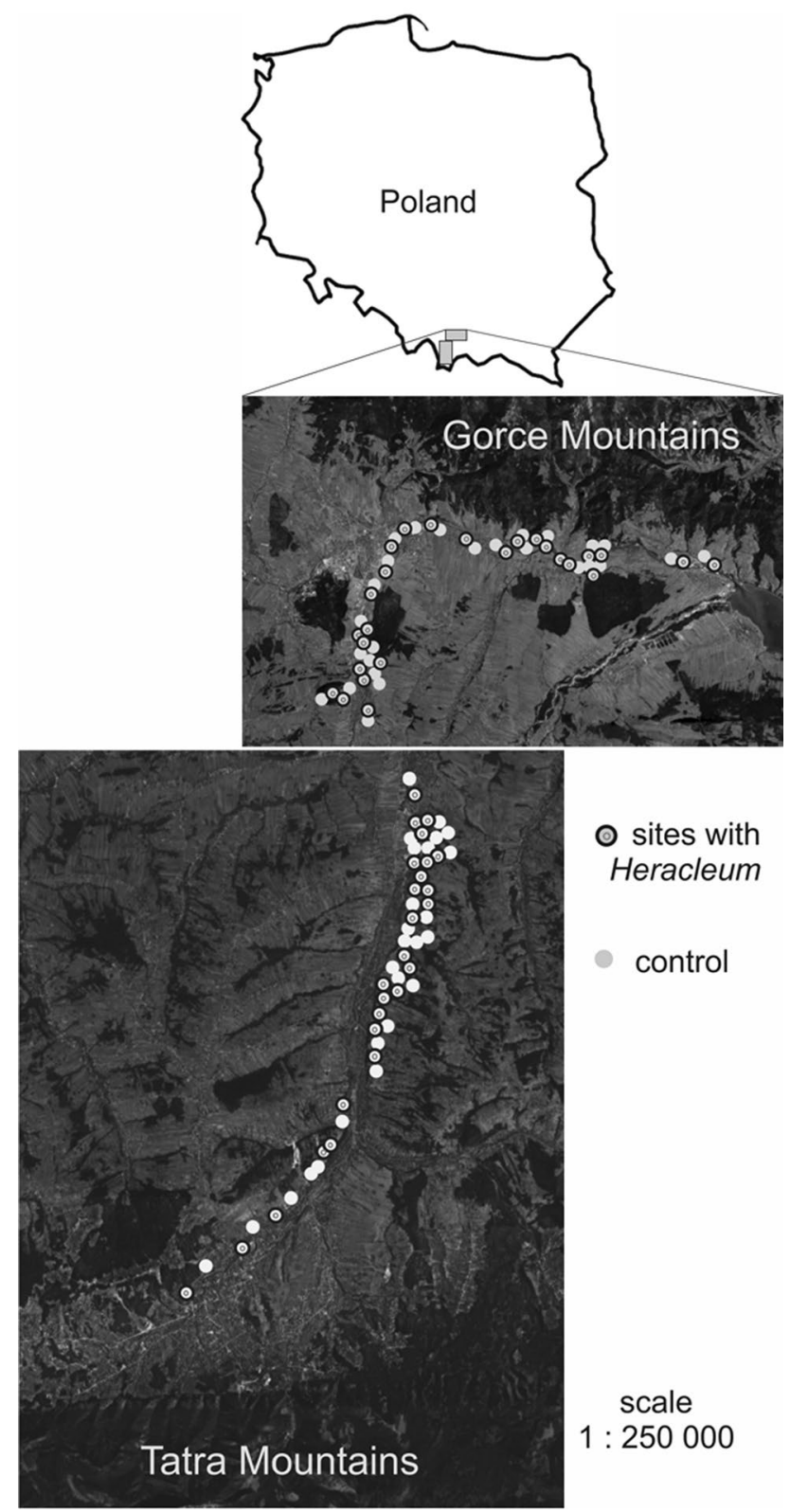

Fig. 1 Map with the locations of the study sites (52 with Sosnowsky's Hogweeds and 52 control) in southern Poland marked with dots on the satellite map (free background source: geoportal.gov.pl)

\section{Methods}

\section{Study area with invasion}

The research was conducted in southern Poland in 2019 along three river valleys (Fig. 1). Sosnowsky's Hogweed is the only Caucasian hogweed species in this area. This invader was present in all river valley habitats, and its patches had a diverse form-from single plants through medium-sized patches (up to several meters in diameter) to several places where the number of Sosnowsky's Hogweed 
was hundreds of plants in patches with the area up to 1 hectare. The most extreme invasion patches were found both in meadows and forests. Individuals developing flower shoots reached various heights from 0.5 to $3 \mathrm{~m}$, although plants above $2.5 \mathrm{~m}$ were relatively rare in the study area.

Our study was done on 104 sites set in 52 pairs where one site in the pair was control without invasion (hereafter called "control"), while the second one was covered in $25-90 \%$ (on average $50 \%$ ) by invasive Sosnowsky's Hogweeds (hereafter called "Heracleum"). Within a given pair, both sites were located in the same habitat (meadow, wasteland, bush wood along the riverside, forest, etc.) and topographically similar locations, i.e. on flat terrain and at similar distances from rivers and mountains (Fig. 1). The distance between site centers within a given pair varied from 250 to $500 \mathrm{~m}$ and the distances between adjacent pairs were from $300 \mathrm{~m}$ to $2 \mathrm{~km}$. Each study site was a circle with a diameter of $50 \mathrm{~m}$ selected in a habitat appropriate for counting birds, i.e. away from potential disturbances that might affect the results (for more details see: Grzędzicka and Reif 2020). Within this 50-m radius, we recorded following Sosnowsky's Hogweed characteristics at the periods when bird counts were performed (for more details, see Table S1-Supplementary information): coverage (specified per each invasion patch in percent covering the $50-\mathrm{m}$ radius site and then summed up for the whole site, as the invasion per site included several small patches of hogweeds-lower cover of hogweeds means overdispersed distribution of the invader, i.e. a higher patchiness), the number of specimens of this species (a complete count of all hogweed plants counted separately in invasion patches within the 50-m plots and then summed up), the maximum height (the tallest hogweed plant found in the 50-m plot), and the number of flowering plants of the invader (based on plant counts in invasion patches within the 50-m plots and then summed up). We did our best to match all characteristics but invasion for both sites within each pair. To confirm that there were no differences, we used a satellite map in Google Maps to measure the areas (in hectares) of four types of elements for each 50-m plot: open areas (meadows, fields), areas covered with bushes and trees, linear elements (balks, paths, streams, river fragments, power line belts), built areas (houses, gazebos, apiaries, energy stations) for comparison. Kruskal-Wallis tests did not indicate any significant differences between Heracleum and control sites in any of these measures (see Table $\mathrm{S} 2$ for test results).

\section{Bird censuses}

Birds were counted in all pairs of study sites (control and Heracleum, see above) by one observer (EG). On each study site, the birds were counted in three dates selected according to invader's phenology: first count: 25.04-20.05.2019 (Sosnowsky's Hogweed was visible in the field), second count:
21.05-11.06.2019 (Sosnowsky's Hogweed full development of green parts), 3rd count: 12.06-15.07.2019 (Sosnowsky's Hogweed had flowers), with a minimum interval of 14 days between counts at a particular site. Paired sites were surveyed on the same day and time (within an interval of max. $1 \mathrm{~h}$ ). Each count consisted of recording all birds seen and heard within a radius of $50 \mathrm{~m}$ from the counting point (Aravind et al. 2010) for $10 \mathrm{~min}$. The counts were performed from sunrise until 11 a.m. (Hanowski and Niemi 1995). We did not consider aerial feeders, shorebirds, gulls, terns and raptors (for more details see: Grzędzicka and Reif 2020). To perform the analysis on bird feeding guilds, all species were sorted into insectivores, granivores and omnivores based on the literature information on main food items known for adults and nestlings during the breeding season (Cramp 1977-1994, Table S3-Supplementary information). Additionally, we also divided insectivorous birds into the ground/ herb and bush/tree insectivores based on field observations concerning foraging habitat used by adult birds during the breeding season (Table S3, for more details concerning classification, see: Grzędzicka and Reif 2020).

\section{Statistical analysis}

All statistical analyses were prepared in the $R 3.6 .2$ software ( $\mathrm{R}$ core team 2019). To test the impact of Sosnowsky's Hogweed on the abundance of birds from different feeding guilds (bush/tree insectivores, ground/herb insectivores, granivores, omnivores) based on results from three counts (all counts treated separately), we used generalized linear mixed-effects models (GLMMs) fitted with the glmer function in the lme4 package (Bates et al. 2015). In each model, the number of individuals from a given bird guild was a response variable with Poisson distribution and logarithmic link function, while the only explanatory variable was the group (0-control, 1-Heracleum). The fit of the model was assessed by the maximum likelihood, while "site ID" (identification of the 50-m radius site used for bird count, $N=104$ ) and "count ID" (the identity of bird count: first, second, third) were treated as the random effects. The results of the GLMM models were visualized using boxplots prepared within the functions from packages: ggplot2 (Wickham 2016) and dplyr (Wickham et al. 2020).

Another analysis tested the influence of invasion development stages on the abundance of bird guilds. To check whether hogweeds' characteristics in particular stages are correlated and provide the same or different information, we illustrated relationships between characteristics per each bird count using corrplot function in corrplot package (Wei and Simko 2017). To test the impact of different Sosnowsky's Hogweed characteristics reflecting the influence of its phenological development throughout the breeding season on bird guilds, we designed models with data only from 
Heracleum sites, using glmer function in the lme4 package (Bates et al. 2015). The number of birds from a given feeding guild was a response variable with Poisson distribution and log link function. The Sosnowsky's Hogweed characteristics were explanatory variables: its percentage cover, the number of invader specimens, its maximum height per site and the number of Heracleum specimens with flowers per site-for more information see Table S1. In these models, "site ID" $(N=52)$ was used as the random effect to account for pseudoreplication associated with three bird counts at the same sites. We did not include "count ID" as the random effect, because it would reduce the expected impacts of hogweed features developing differently at each site according to the local conditions and noted separately on each count. We checked the problem of multicollinearity in each model with the variance inflation factor VIF values using two packages: performance and see (Lüdecke et al. 2020). In all cases, VIF was below 2.0 indicating low multicollinearity (Kim 2019). Scatterplots with the relationships between the abundance of birds from different feeding guilds and Sosnowsky's Hogweed characteristics were prepared in the ggplot2 package (Wickham 2016).

To test the effects of development stages of Sosnowsky's Hogweed on the species-specific responses of birds, which may differ from those of guilds of birds, the canonical correspondence analysis (CCA) was performed on abundances of each species using the vegan package (Oksanen et al. 2019). In this analysis, we divided the results of bird counts at Heracleum sites into two parts: before flowering and during flowering. This separation was to test the effects of development stages of Sosnowsky's Hogweed distinguishing the flowering period which is most attractive to pollinators. We prepared two separate CCAs-one for the first two counts (before flowering) where we considered the highest of these two counts as the abundance of each species, and the second one for the third count (during the flowering period). The explanatory environmental variables (expressed for each site) were: Sosnowsky's Hogweed percentage cover, Sosnowsky's Hogweed number, and Sosnowsky's Hogweed maximum height. Moreover, we further included the number of Heracleum flowering specimens per site in addition to the other explanatory variables in the case of CCA for the third count. The relationships revealed by CCA were tested by anova cca function using the "terms" method. Besides, we used vif cca function to control the aspect of multicollinearity among model parameters and in all cases, the values of VIF were below 3.0, i.e. low (Kim 2019). The results of CCA were visualized in the ordination diagrams using the scores along the first two axes of CCA (Granadeiro et al. 2007).

To investigate the potential mechanism of a positive influence of Heracleum feature on the abundance of ground/herb insectivorous birds after the GLMM showed such an effect, we calculated the correlation coefficient between the cumulative abundance of those birds at the species level and the potential availability of their food base on hogweeds. The maximum count across three visits at each point for each ground/herb species was considered as the abundance of this species at a single study site. We summarized the abundances of each species from all Heracleum sites $(N=52)$ and used those values (one sum per species) as cumulative abundances of species belonging to the guild of ground/herb insectivores. Data concerning their potential food accessibility on hogweeds were prepared based on publications found separately for each species. The literature search was done by entering the Latin name of a single bird species and two words: "diet" and "pdf" in google.pl web browser. Then, we chose the first article from Europe and calculated what percentage of the bird's diet were insects belonging to Hymenoptera, Diptera, Coleoptera, Hemiptera, and Lepidoptera that could be found on Caucasian hogweeds (according to: Grace and Nelson 1981; Satsyperova 1984; Hansen et al. 2006; Ustinova et al. 2017). Shapiro-Wilk test showed normal distribution of the cumulative abundance of ground/herb insectivores from Heracleum sites ( $W=0.661, P=0.0001$ ), while the distribution of the percentage of those species' food items potentially available on hogweeds differed from normality ( $W=0.966 ; P=0.816$ ). Therefore, we used Pearson correlation coefficient to check the relationship between species-level ground/herb insectivore abundances and their food resources potentially available on hogweeds. Scatterplot showing the test result was prepared using the ggplot2 package (Wickham 2016).

\section{Results}

\section{Hogweed seasonal development}

The number and coverage of Sosnowsky's Hogweeds per site were correlated, especially during the first bird count. The cover and height of hogweeds correlated weakly positively on the second and more strongly on the third count (for correlation values see Fig. S1-Supplementary information). Comparing three consecutive counts, the mean hogweed coverage per site increased by approx. 5\% between the first and second count and $1 \%$ to the third count, while the mean number of plants remained similar. The average height growth was $70-80 \mathrm{~cm}$ between counts (Table 1). During the first two counts of birds, Sosnowsky's Hogweeds did not bloom on sites. The flowering of hogweeds was recorded on 41 sites (78.8\% of Heracleum ones). The mean number of flowering plants per site was 94 (in average $51.4 \%$ of the invaders present in the research site, ranging from 0 to 600-Table 1), while the rest were plants developing only green leaf rosettes. The height of hogweeds was independent 
Table 1 Sosnowsky's Hogweed average characteristics for each field inspection separately, determined within $50 \mathrm{~m}$ from the counting point; the ranges of recorded values on 52 points are given in brackets

\begin{tabular}{llll}
\hline Variable & First count & Second count & Third count \\
\hline Heracleum cover & $49.23 \%(25-90 \%)$ & $54.33 \%(25-90 \%)$ & $55.38 \%(25-90 \%)$ \\
Heracleum number & $172(10-1000)$ & $176.5(10-1000)$ & $183(10-1000)$ \\
Heracleum height & $48.3 \mathrm{~cm}(20-100 \mathrm{~cm})$ & $130 \mathrm{~cm}(50-150 \mathrm{~cm})$ & $202 \mathrm{~cm}(50-250 \mathrm{~cm})$ \\
Heracleum flowering number & 0 & 0 & $94(0-600)$ \\
\hline
\end{tabular}

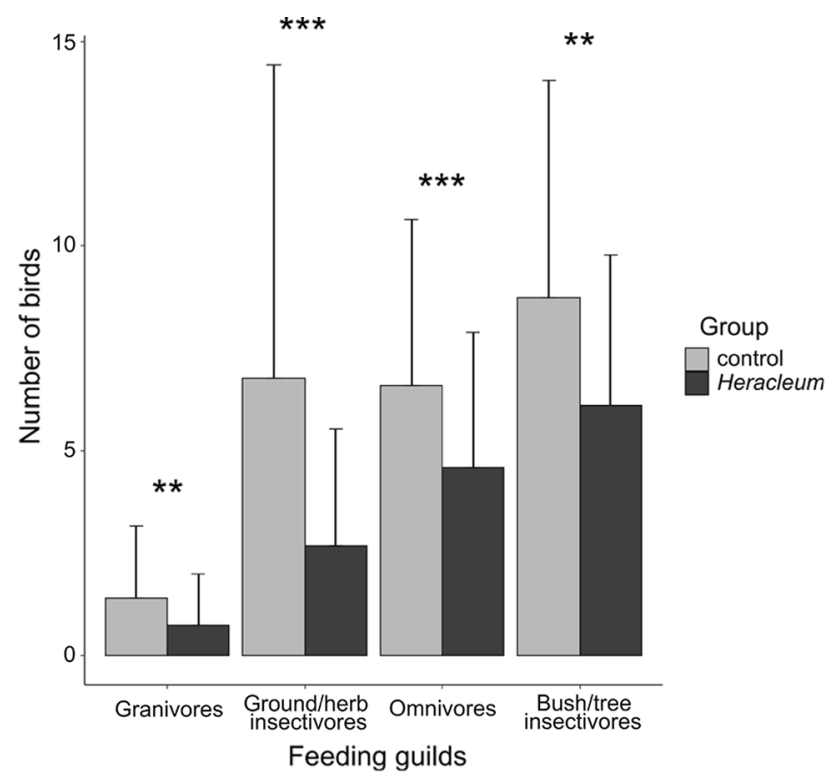

Fig. 2 Column graphs showing differences in the bird abundance from each feeding guild between Heracleum and control sites, where "site ID" and "count ID" were the random effects, while group of sites (0-control, 1-Heracleum) was a nominal factor, $P$ values: ** less than 0.001 , *** less than 0.0001 , error bars are standard deviations (number of observation sets during three counts: $N=312$, number of sites: $N=104$ )

of number and cover, while the likelihood of flowering was greatest in the tallest specimens. The number of flowering hogweeds was correlated with the number of all hogweeds per site (Fig. S1).

\section{The effect of hogweeds on bird feeding guilds}

Across all 3 counts, 72 species of birds were recorded; 71 species were at control sites, 61 species were at Heracleum sites. The numbers of birds summed up from all control sites during the first count were: 71 granivores, 193 ground/herb insectivores, 278 omnivores, 380 bush/tree insectivores; during the second count: 75 granivores, 306 ground/herb insectivores, 333 omnivores, 516 bush/tree insectivores; during the third count: 65 granivores, 529 ground/herb insectivores, 390 omnivores, $430 \mathrm{bush} /$ tree insectivores. The numbers of birds summed up from all Heracleum sites during the first count were: 34 granivores, 113 ground/herb insectivores, 249 omnivores, $333 \mathrm{bush} /$ tree insectivores; during the second count: 50 granivores, 160 ground/herb insectivores, 270 omnivores, 395 bush/tree insectivores; during the third count: 30 granivores, 182 omnivores, 136 ground/herb insectivores, $205 \mathrm{bush} /$ tree insectivores.

The presence of Sosnowsky's Hogweed negatively impacted the abundance of birds from all feeding guilds (Fig. 2). Specifically, at the sites with hogweeds was lower abundance of granivores (GLMM: Estimate $\pm \mathrm{SE}=-0.639 \pm 0.202, \quad Z=-3.168$, $P=0.001$ ), ground/herb insectivores (GLMM: Estimate $\pm \mathrm{SE}=-0.933 \pm 0.143, Z=-6.537, P<0.0001)$, omnivores (GLMM: Estimate $\pm \mathrm{SE}=-0.355 \pm 0.088$, $Z=-4.013, P<0.0001)$, and bush/tree insectivores (GLMM: Estimate $\pm \mathrm{SE}=-0.307 \pm 0.098, Z=-3.135$, $P=0.002$ ) than at control sites (Fig. 2). When focusing on Sosnowsky's Hogweed characteristics at Heracleum sites and the number of birds from three counts, we found a significant positive relationship between the invader's number and the abundance of ground/herb insectivores (Table 2, Fig. 3), which can reflect the availability of food items on hogweeds. The abundance of ground/herb birds at the species level was shown to be positively correlated with the percentage of food items known from their diet that was potentially available on hogweeds (Pearson correlation coefficient: $R=0.56, P=0.035$, Table 3, Fig. 5). Bush/tree insectivores were negatively affected by hogweed height (Table 2, Fig. 3). The number of flowering invaders negatively affected the abundance of omnivores (Table 2, Fig. 3). The number of granivores was not impacted by Sosnowsky's Hogweed characteristics (Table 2).

\section{The effect of hogweed seasonal development on bird species}

During the first 2 counts, 61 species of birds were recorded at the sites with Sosnowsky's Hogweed. When we related the abundance of individual bird species to respective invasion features using CCA (Table S4, Fig. 4), first two axes (CCA1 and CCA2) explained $53.8 \%$ and $26.9 \%$ of the variance, respectively, and their eigenvalues were 0.158 and 0.079 , respectively. CCA1 corresponded to the 
Table 2 Results of the GLMM models with the bird abundance from each feeding guild from Heracleum sites as a dependent variable, where "site ID" was the random effect, while Sosnowsky's Hogweed features were the continuous factors (number of observation sets across all three counts: $N=156$, number of sites: $N=52$ )

\begin{tabular}{|c|c|c|c|c|}
\hline & \multicolumn{4}{|c|}{ Number of ground/herb insectivorous birds } \\
\hline & Estimate $\pm \mathrm{SE}$ & $z$ value & $p$ value & $\mathrm{VIF} \pm$ increased $\mathrm{SE}$ \\
\hline (Intercept) & $1.574 \pm 0.461$ & 3.130 & 0.002 & \\
\hline Heracleum cover & $-0.011 \pm 0.006$ & -1.518 & 0.129 & $1.97 \pm 1.40$ \\
\hline Heracleum number & $0.006 \pm 0.001$ & 2.193 & 0.028 & $1.97 \pm 1.40$ \\
\hline Heracleum height & $-0.004 \pm 0.003$ & 1.197 & 0.231 & $1.38 \pm 1.17$ \\
\hline \multirow[t]{3}{*}{ Heracleum flowering number } & $0.0004 \pm 0.001$ & -0.011 & 0.991 & $1.34 \pm 1.16$ \\
\hline & \multicolumn{4}{|c|}{ Number of bush/tree insectivorous birds } \\
\hline & Estimate $\pm \mathrm{SE}$ & $z$ value & $p$ value & $\mathrm{VIF} \pm$ increased $\mathrm{SE}$ \\
\hline (Intercept) & $1.793 \pm 0.154$ & 11.604 & $<0.0001$ & \\
\hline Heracleum cover & $0.006 \pm 0.003$ & 1.784 & 0.074 & $1.88 \pm 1.37$ \\
\hline Heracleum number & $-0.0005 \pm 0.0004$ & -1.468 & 0.142 & $1.91 \pm 1.38$ \\
\hline Heracleum height & $-0.002 \pm 0.001$ & -3.290 & 0.001 & $1.38 \pm 1.17$ \\
\hline \multirow{3}{*}{ Heracleum flowering number } & $-0.001 \pm 0.0006$ & -1.856 & 0.063 & $1.38 \pm 1.17$ \\
\hline & \multicolumn{4}{|c|}{ Number of granivorous birds } \\
\hline & Estimate $\pm \mathrm{SE}$ & $z$ value & $p$ value & $\mathrm{VIF} \pm$ increased $\mathrm{SE}$ \\
\hline (Intercept) & $-1.060 \pm 0.426$ & -2.710 & 0.007 & \\
\hline Heracleum cover & $0.009 \pm 0.006$ & 0.959 & 0.337 & $1.83 \pm 1.35$ \\
\hline Heracleum number & $-0.0001 \pm 0.001$ & -0.056 & 0.956 & $1.86 \pm 1.37$ \\
\hline Heracleum height & $0.002 \pm 0.002$ & 1.318 & 0.187 & $1.46 \pm 1.21$ \\
\hline \multirow[t]{3}{*}{ Heracleum flowering number } & $-0.001 \pm 0.001$ & -1.145 & 0.252 & $1.47 \pm 1.21$ \\
\hline & \multicolumn{4}{|c|}{ Number of omnivorous birds } \\
\hline & Estimate $\pm \mathrm{SE}$ & $z$ value & $P$ value & $\mathrm{VIF} \pm$ increased $\mathrm{SE}$ \\
\hline (Intercept) & $1.302 \pm 0.182$ & 7.161 & $<0.0001$ & \\
\hline Heracleum cover & $0.006 \pm 0.004$ & 1.622 & 0.105 & $1.80 \pm 1.34$ \\
\hline Heracleum number & $-0.0003 \pm 0.0004$ & -0.663 & 0.507 & $1.80 \pm 1.34$ \\
\hline Heracleum height & $-0.001 \pm 0.001$ & -0.973 & 0.331 & $1.35 \pm 1.16$ \\
\hline Heracleum flowering number & $-0.002 \pm 0.001$ & -2.671 & 0.008 & $1.33 \pm 1.15$ \\
\hline
\end{tabular}

increasing representation of the invader at the study sites and was significantly associated with its height (Table S4, Fig. 4), whereas CCA2 showed a gradient from sites with a high number of Heracleum stems to sites with its high coverage (Fig. 4). According to GLMM, the abundance of ground/herb insectivores was positively related with the hogweed number (Table 2) as also indicated by positions of individual species (such as Tree Pipit Anthus trivialis or Dunnock Prunella modularis) at the negative part of the CCA2 (Fig. 4). Ground/herb insectivores were negatively impacted by tall Sosnowsky's Hogweeds, reflected by positions of, for example, Stonechat Saxicola rubicola, Robin Erithacus rubecula and House Martin Delichon urbicum at the negative part of CCA1 (Fig. 4). Like bush/ tree insectivores' feeding guild (Table 2), most strongly responding individual species in this group appeared at the negative part of the CCA1, which suggests their avoidance of tall specimens (Fig. 4). CCA repeated the results of the GLMM model and showed no significant trends in abundance of granivores depending on Sosnowsky's Hogweed, although e.g. granivore Linnet Linaria cannabina and Goldfinch Carduelis carduelis avoided tall Heracleum as indicated by their positions at the negative part of the CCA1 (Fig. 4). The positions of some omnivores at the negative part of CCA1 reflected the negative effect of hogweed height on those species, e.g. omnivore Jackdaw Corvus monedula, Rook Corvus frugilegus (Fig. 4).

During the third counts at Heracleum sites, 31 bird species were recorded (Table S3). In the CCA analysis, CCA1 and CCA 2 explained $52 \%$ and $22.8 \%$ of the variance, 
Fig. 3 Scatterplots showing relationships between Sosnowsky's Hogweed characteristics (measured separately at each of three bird counts) and the number of birds from feeding guilds counted during three field inspections; plots are based on models with "site ID" as the random effect from Table 2 designed on data only from Heracleum sites (number of observation sets during three counts: $N=156$ )
Table 3 List of bird species belonging to the guild of ground/herb insectivores pooled across all Heracleum study sites
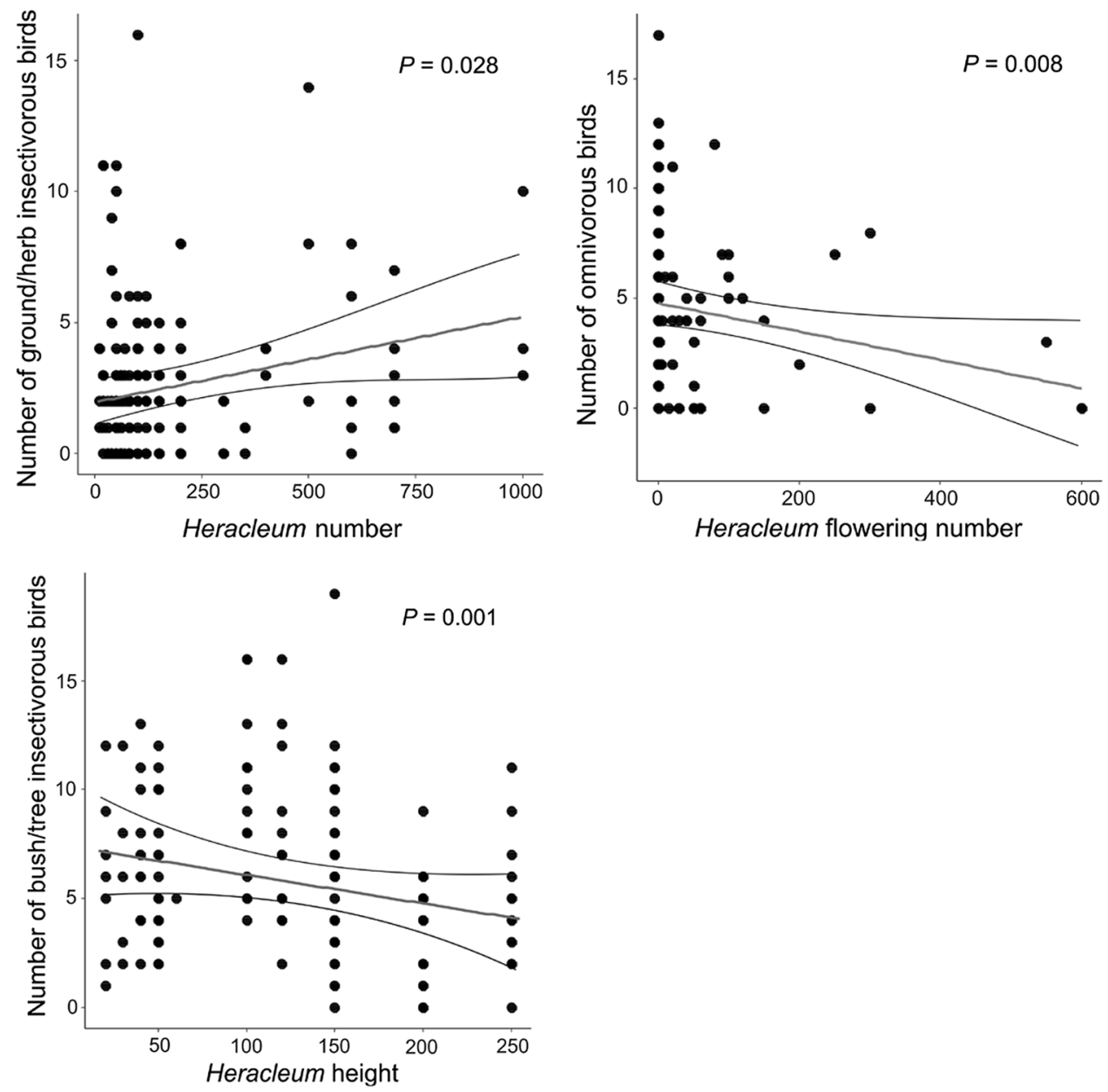

\begin{tabular}{llll}
\hline Bird species & No. of birds & Diet (\%) & References \\
\hline Alauda arvensis & 24 & 37 & Geiger et al. (2014) \\
Acrocephalus scirpaceus & 26 & 66.5 & Grim and Honza (1996) \\
Delichon urbicum & 13 & 80.25 & Boukhemza-Zemmouri et al. (2013) \\
Hirundo rustica & 45 & 96.3 & Orłowski and Karg (2011) \\
Troglodytes troglodytes & 18 & 12.6 & Krištín (1990) \\
Sturnus vulgaris & 110 & 83.8 & Motis et al. (1997) \\
Erithacus rubecula & 10 & 22.9 & Krištín (1990) \\
Phoenicurus ochruros & 1 & 63 & Nicolai (2001) \\
Saxicola rubetra & 5 & 43 & Pudil and Exnerová (2015) \\
Saxicola rubicola & 1 & 31.7 & Dyrcz and Flinks (1995) \\
Prunella modularis & 1 & 4.7 & Krištín (1989) \\
Anthus trivialis & 1 & 38 & Krištín and Exnerová (1994) \\
Motacilla cinerea & 14 & 26.5 & Belkacem et al. (2019) \\
Motacilla alba & 15 & 50 & Davies (1976) \\
\hline
\end{tabular}

The table shows what percentage of the diet of these species are food items that are potentially available on Sosnowsky's Hogweed 

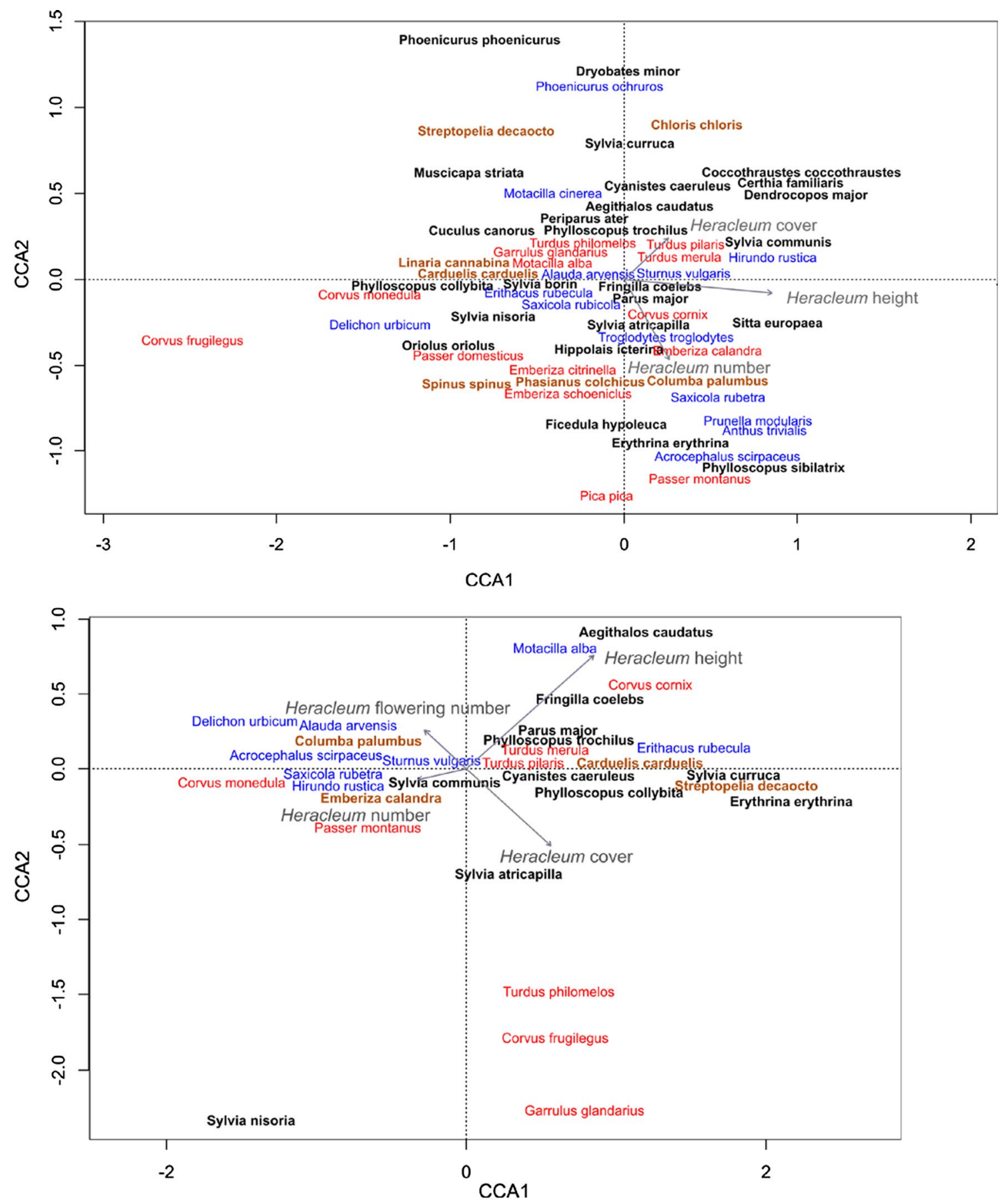

Fig. 4 Results of the CCA analyses showing the responses of different bird species observed at Heracleum sites to the characteristics of Sosnowsky's Hogweed development stage before flowering (upper graph) and during flowering period (graph below). Bird guilds marking on the chart: ground/herb insectivores - blue font, bush/tree insectivores - bold font, omnivores - red font, granivores - brown font (color figure online)

impact of Sosnowsky's Hogweed showed by GLMMs: negative impact of height on some bush/tree insectivores (especially Barred Warbler Sylvia nisoria and Blackap Sylvia atricapilla), the positive impact of a number on ground/ herb insectivores, no significant impact on granivores, and respectively, and their eigenvalues were 0.285 and 0.125 , respectively. CCA1 was the most strongly and positively associated with Sosnowsky's Hogweed height, whereas CCA2 was related to its cover and number (Table S5, Fig. 4). The ordination diagram showed tendencies confirming the 


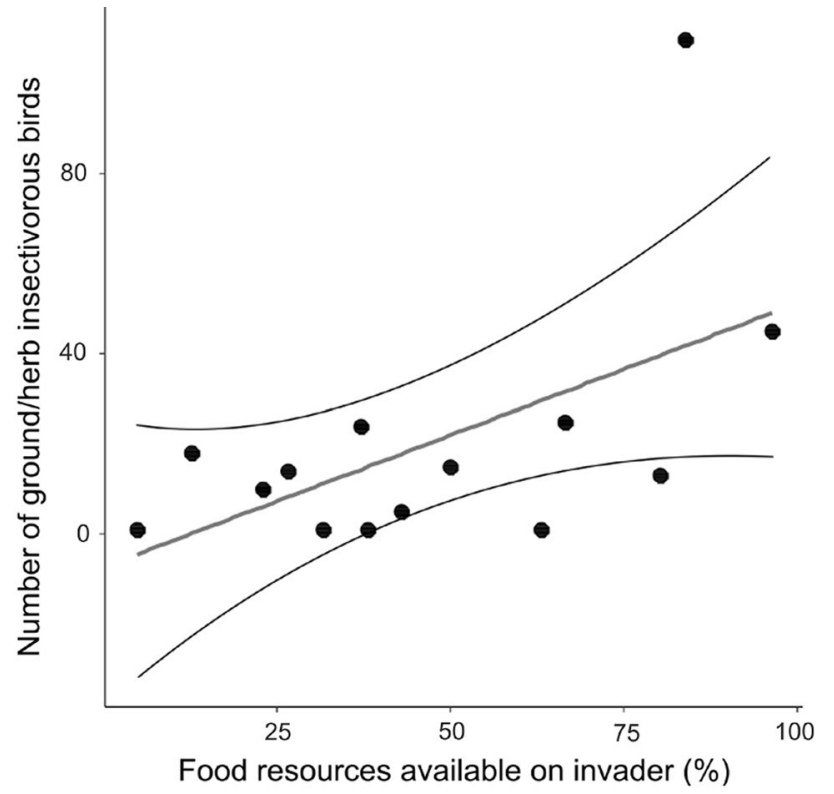

Fig. 5 Scatterplot showing the positive correlation between the summarized abundance of ground/herb insectivores at a species level from Heracleum sites and the percentage of those species' food items potentially available on Sosnowsky's Hogweed

negative influence of flowering plants number on the omnivorous birds (Fig. 4). The positions of some species at the negative part of CCA1 confirmed that they were supported by a large number of Sosnowsky's Hogweed specimens, e.g. Tree Sparrow Passer montanus, Jackdaw, Corn Bunting Emberiza calandra, Wood Pigeon Columba palumbus, Barn Swallow Hirundo rustica (Fig. 4). Others appeared at the positive part of CCA1, i.e. near tall invaders, e.g. Hooded Crow Corvus cornix, Long-tailed Tit Ageithalos caudatus, Chaffinch Fringilla coelebs. Three species of birds belonging to the omnivores strongly avoided a large number of flowering Sosnowsky's Hogweeds: Jay Garrulus glandarius, Rook and Song Thrush Turdus philomelos (Fig. 4), which confirms the result of GLMM (Table 2).

\section{Discussion}

The presence of Sosnowsky's Hogweed negatively affected the number of birds from all feeding guilds. We confirmed the predictions about different effects of the invasion on ground/herb insectivores and bush/tree insectivores, although rejected hypothesis concerning the positive effect of hogweed seeds' availability on the presence of granivores and omnivores. The studied invasion may impact birds not only by limiting the food base of granivores and omnivores but also unexpectedly that of insectivorous birds, although Sosnowsky's Hogweeds are considered attractive to many insects (Grace and Nelson 1981; Satsyperova 1984; Ustinova et al. 2017). The relationships we have reported may be due to three types of mechanisms: food accessibility, the impact of invasion physiognomy, or its chemical properties, which all might affect various feeding guilds differently, depending on the presence or absence of hogweeds.

In general, our results concerning the negative impact of hogweeds on all feeding guilds correspond to studies on other invasive plants showing that they decrease the availability of bird food (e.g. Aravind et al. 2010; Skórka et al. 2010; Mangachena and Geerts 2017). Although we expected that a higher cover of hogweeds will support the availability of food for insectivorous birds, we showed that the number of hogweeds was positively related to the abundance of ground/herb insectivores likely indicating increased food availability. It is known that in some situations, alien plants can be a source of additional food, for example for frugivores, especially under resource-limited conditions (Reichard et al. 2001; Chupp and Battaglia 2016). Our research showed for the first time a similar phenomenon in the ground/herb insectivorous birds. Based on data from the literature on the ground/herb insectivores diet and our results of bird counting, we have shown that particular species from this guild could appear near hogweeds if there was a possibility that they would find food there (Table 3 , Fig. 5). In the case of omnivorous birds, a factor limiting this group was the number of flowering hogweeds. Omnivorous birds are often facultative granivores and sites with numerous flowering hogweeds imply a greater seed availability in the soil (from previous years). Hogweed seeds are probably unsuitable for these birds and may limit the access to the more suitable seeds driving the negative impact. In contrast, strict granivores may have adapted to Sosnowsky's Hogweed seeds since no such negative effects were demonstrated. Nevertheless, although we have provided some circumstantial evidence that hogweeds could impact birds through a food-related dependence (negative as was in the case of omnivores or positive as in ground/herb insectivores), we have not proved by controlled experiment this to be the mechanism. Perhaps the fact that all the guilds did not respond to hogweeds in accord with the food-mediated hypotheses indicates that food mediates only some feeding guilds of birds under certain circumstances.

The impact of plant invaders on birds may be driven directly by the physical structure of the vegetation rather than indirectly through the food base. We found that various aspects of the invasive plant occurrence impacted respective bird feeding guilds differently. Ground/herb insectivores appeared on patches with more hogweeds, while bush/tree insectivores avoided tall invaders, which supports our prediction about different effects of lower and higher parts of hogweeds on those two bird guilds. However, the positive relationship between ground/herb insectivore abundance and the number of Sosnowsky's 
Hogweed specimens may not be an indication for the preference of these birds for this invasive plant. Indeed, on sites with more hogweeds, these birds could also find gaps with native vegetation between numerous competing plants weakly developed in their lower parts. More plants meant a weaker development of hogweeds in a patch due to their greater competition for space and smaller leaf spread, between which birds feeding on the ground could find other vegetation and food (personal observation). Nevertheless, in a wider perspective, this may be another mechanism of the negative impact of the invasion on this group of birds. If ground/herb insectivores prefer to forage in native vegetation, the growing presence of hogweeds on sites decreases its availability and quality negatively affecting also the abundance of birds that, at the beginning, are trying to cope with hogweeds by choosing sites with their highest number and some native vegetation. To support this, in another paper, we showed that ground-related habitat specialists were negatively impacted by Sosnowsky's Hogweeds especially in open areas (Grzędzicka and Reif 2020) where numerous hogweeds do not compete with woody vegetation and grow in dense thickets, invading meadows and thus negatively impacting ground/herb insectivores. The meaning of hogweed physical properties seems to be confirmed by exceptions to the rule, e.g. ground/herb insectivore Grey Wagtail Motacilla cinerea avoided a high density (number) of hogweeds before flowering (Fig. 4), because it searches for food along rivers and treats the bank vegetation with native plants between hogweeds not for foraging but rather as a shelter (personal observation), not provided by too high density of hogweeds.

The pattern for bush/tree insectivores is also in good accord with the ecology of this guild: they were negatively impacted by hogweeds' height, because tall herbs cannot replace the woody plants they need. In the line with studies on other invaders (Walker 2008; Osborne et al. 2012), it can be presumed that for bush/tree insectivores searching for insects from higher positions, the greater cover or number of Sosnowsky's Hogweeds was not important as it did not disturb the effective food searching. Interestingly, some bush/tree insectivores, e.g. Garden Warbler Sylvia borin and Barred Warbler, avoided high cover of hogweeds before flowering, probably due to their different habitat preferences. To our knowledge, we are not aware of any analogies in another invasive plant-bird systems to the differences between ground/herb insectivores and bush/ tree insectivores responses to Sosnowsky's Hogweed we report here.

Any negative impacts of the studied invasion on all bird guilds can be also explained by the effect of Sosnowsky's Hogweed properties. The vegetation of patches with invasive hogweeds is species-poor with a significant share of generalist plant species (Śliwiński and Anioł-Kwiatkowska 2011) which certainly reduces biodiversity including the availability of plant and insect food. This may be caused by a herbicidal potential of this invader (Gala-Czekaj et al. 2018) and a high concentration of biologically active compounds in its tissues (Budarin and Kondratyev 2014). It is known that the total phenols content is mainly in leaves (Baležentienẻ 2015). However, in all parts of hogweeds is also juice containing coumarin derivatives, esters, alcohols and long-chain hydrocarbons (Hattendorf et al. 2007) and thus, they are toxic to vertebrates, invertebrates, fungi, bacteria and viruses (Pyšek et al. 2007). Those plant extracts were once used as an insecticide, as they interfere with the aquatic mechanism of insects, directly affecting their neuromuscular system (Jõgar et al. 2006). Chemicals from hogweeds might accumulate in insects, causing them to be poisonous to consumers in excess (e.g. birds), which may explain the attraction of these plants to some insects, but not to other animals.

Our research was conducted in dates to match Sosnowsky's Hogweeds development when its effects on birds can be expected. This could lower species detectability according to their phenology, as e.g. songbirds may be most detectable early in the breeding season (Sliwinski et al. 2016). Moreover, detectability of birds varies by species, habitat, observer and many other factors (Buckland et al. 2008), and to avoid risk connected with those factors, control and Heracleum sites were designated in the same habitats and land covers. Large patches of hogweeds, however, could decrease bird detectability. We do not think that this problem was present in our data since ground/herb insectivores, i.e. species that should be theoretically least detectable in Sosnowsky's Hogweed stands, had indeed higher counts in invaded sites with a higher Sosnowsky's Hogweed number. The proximity of large plants, in which birds could hide if necessary, could make them less shy. Our observations so far show that highly developed hogweeds may be used as an observation point and by singing males, which supports the visibility of birds. Birds are more skittish in sparse vegetation, so paradoxically they could be less detectable in control areas. Other authors have shown that the influence of habitat on detectability is small for most species compared to the important effect of the observer, as well as whether the bird was seen or heard (van Heezik and Seddon 2012). Therefore, taking into account that the birds were counted quite late in the season when the singing was no longer intense and it was necessary to know other bird voices and behaviors, the fieldwork was carried out on small sites by one experienced observer to increase species detectability and ensure it is comparable across all sites. The 50-m radius seems adequate, it generates density estimates twice as high as $100-\mathrm{m}$ radius counts (Reidy et al. 2011). The size of the sample (104 points) is also important, as it seems to be sufficient 
to detect the impact of hogweeds on all species that can be detected in the study area. It is known that 4 points on the grid are enough to detect common species, while at least 64 points are needed to observe rare species with low detection probability (Sliwinski et al. 2016). Even though our research was not based on the grid, it also concerns a specific coherent area and the number of points seems to be sufficient to record less detectable birds.

In sum, we confirmed the different effects of hogweeds' spatial development on insectivorous birds feeding at different levels, which are in line with the ecology of these birds. However, due to the negative impact of hogweeds on the abundance of birds from all feeding guilds, the positive relationships of some birds to particular invasion features (e.g. ground/herb insectivores to the number of hogweeds) seem to be rather an attempt to cope with the parameters of habitat altered by Sosnowsky's Hogweeds occurrence rather than a conscious selection of these plants by animals searching for food. Sosnowsky's Hogweed strongly transformed the habitat of ground/herb insectivores, which contributed to the loss of food sources and the need to look for it near hogweeds. Sosnowsky's Hogweed invasion is so harmful that even bird guilds such as granivores and omnivores probably did not use the potentially large availability of beneficial food (seeds). Our results confirm statements of other authors suggesting that in future, plant invasions may result in the formation of new assemblages (Beachy and Robinson 2009) and currently unpredictable changes in bird ecology (Witmer 1996; Reichard et al. 2001).

Supplementary Information The online version contains supplementary material available at https://doi.org/10.1007/s10336-021-01898-6.

Acknowledgements The authors kindly thank to the three anonymous referees for valuable comments that helped to improve the paper. During the study preparation EG was supported by National Science Centre in Kraków, Poland (grant Sonatina 2-NZ no. 2018/28/C/NZ8/00283), while JR by Charles University, Prague (grant no. PRIMUS/17/ $\mathrm{SCI} / 16)$.

Author contribution EG and JR together worked on concept of the manuscript and statistical analyses, EG collected field data, prepared data base and analyses, EG and JR together worked on text at all stages.

Funding During the study preparation, EG was supported by National Science Centre in Kraków, Poland (grant Sonatina 2-NZ no. 2018/28/C/ NZ8/00283), while JR by Charles University, Prague (grant no. PRIMUS/17/SCI/16).

Availability of data and materials Data are available upon request.

Code availability R 3.6.2.

\section{Declarations}

Conflict of interest The authors declare no conflict of interest. The research was carried out in accordance with accepted scientific standards and in accordance with the law at the place of field work.

Ethics approval The research was carried out in accordance with accepted scientific standards and in accordance with the law at the place of field work.

Consent to participate Both authors agree to participate in publication.

Consent for publication Both authors agree for publication.

Open Access This article is licensed under a Creative Commons Attribution 4.0 International License, which permits use, sharing, adaptation, distribution and reproduction in any medium or format, as long as you give appropriate credit to the original author(s) and the source, provide a link to the Creative Commons licence, and indicate if changes were made. The images or other third party material in this article are included in the article's Creative Commons licence, unless indicated otherwise in a credit line to the material. If material is not included in the article's Creative Commons licence and your intended use is not permitted by statutory regulation or exceeds the permitted use, you will need to obtain permission directly from the copyright holder. To view a copy of this licence, visit http://creativecommons.org/licenses/by/4.0/.

\section{References}

Aravind NA, Rao D, Ganeshaiah KN, Shaanker RU, Poulsen JG (2010) Impact of the invasive plant, Lantana camara, on bird assemblages at malé mahadeshwara reserve forest, south India. Trop Ecol 51(2S):325-338

Baležentienẻ L (2015) Immediate allelopathic effect of two invasive Heracleum species on acceptor-germination. Acta Biol Univ Daugavp 15(1):17-26

Bates D, Maechler M, Bolker B, Walker S (2015) Fitting linear mixedeffects models using lme4. J Stat Software 67(1):1-48

Beachy BL, Robinson GR (2009) Divergence in avian communities following woody plant invasions in a pine barrens ecosystem. Nat Area J 28:395-403

Belkacem R, Bougaham AF, Gagaoua M, Moulaï R (2019) Food profile of Grey Wagtail Motacilla cinerea during an annual cycle in the Algerian Babors Mountains of North Africa. Ostrich 90(1):45-52

Bogdanov VL, Posternak TS, Pasko OA, Kovyazin VF (2016) The issues of weed infestation with environmentally hazardous plants and methods of their control. IOP Conf Series Earth Environ Sci 43:012036

Boukhemza-Zemmouri N, Farhi Y, Mohamed Sahnoun A, Boukhemza M (2013) Diet composition and prey choice by the House Martin Delichon urbica (Aves: Hirundinidae) during the breeding period in Kabylia, Algeria. Ital J Zool 80(1):117-124

Bourgeois K, Suehs MC, Vidal E, Médail F (2005) Invasional meltdown potential: facilitation between introduced plants and mammals on French Mediterranean islands. Ecoscience 12:248-256

Buckland ST, Marsden SJ, Green RE (2008) Estimating bird abundance: making methods work. Bird Conserv Int 18:91-108

Budarin SN, Kondratyev MN (2014) The use of secondary metabolites Heracleum Sosnowskyi Manden in agriculture. IJSM 1(1):16 
Castro-Díez P, Alonso A (2017) Effects of non-native riparian plants in riparian and fluvial ecosystems: a review for the Iberian Peninsula. Limnética 36(2):525-541

Chupp AD, Battaglia LL (2016) Bird-plant interactions and vulnerability to biological invasions. J Plant Ecol 9(6):692-702

Corlett RT (2005) Interactions between birds, fruit bats and exotic plants in urban Hong Kong, South China. Urban Ecosyst 8:275-283

Cramp SE (1977-1994) The birds of the western palearctic. Oxford Univ Press, Oxford

Dalke IV, Chadin IF, Zakhozhiy IG, Malyshev RV, Maslova SP, Tabalenkova GN, Golovko TK (2015) Traits of Heracleum sosnowskyi plants in monostand on invaded area. PLoS ONE 10(11):e0142833

Davies NB (1976) Food, flocking and territorial behaviour of the Pied Wagtail (Motacilla alba yarrelli Gould) in winter. J Anim Ecol 45:235-254

Doizy A, Barter E, Memmott J, Varnham K, Gross T (2018) Impact of cyber-invasive species on a large ecological network. Sci Rep 8:13245

Dudek K, Michlewicz M, Dudek M, Tryjanowski P (2016) Invasive Canadian goldenrod (Solidago canadensis L.) as a preferred foraging habitat for spiders. Arthropod Plant Interact 10:377-381

Dyrcz A, Flinks H (1995) Nestling and adult diet of the Willie Wagtail Rhipidura leucophrys near Madang, Papua New Guinea. Emu 95:123-126

Foster JT, Robinson SK (2007) Introduced birds and the fate of Hawaiian rainforests. Conserv Biol 21:1248-1257

Gala-Czekaj D, Jop B, Synowiec A (2018) Wpływ mączki z nasion i okwiatu barszczu Sosnowskiego (Heracleum sosnowskyi Manden.) na początkowy wzrost kukurydzy i dwóch gatunków chwastów. Fragm Agron 35(1):29-39

Geiger F, Hegemann A, Gleichman M, Flinks H, de Snoo GR, Prinz S, Tieleman BI, Berendse F (2014) Habitat use and diets of Skylarks (Alauda arvensis) wintering in an intensive agricultural landscape of the Netherlands. J Ornithol 155:507-518

Grace J, Nelson M (1981) Insects and their pollen loads at a hybrid Heracleum site. New Phytol 87(2):413-423

Granadeiro JP, Santos CD, Dias MP, Palmeirim JM (2007) Environmental factors drive habitat partitioning in birds feeding in interdial flats: implications for conservation. Hydrobiologia 587:291-302

Grass I, Berens DG, Farwig N (2013) Guild-specific shifts in visitation rates of frugivores with habitat loss and plant invasion. Oikos 123:575-582

Grim T, Honza M (1996) Effect of habitat on the diet of reed warbler (Acrocephalus scirpaceus) nestlings. Folia Zool 45(1):31-34

Grzędzicka E, Reif J (2020) Impacts of an invasive plant on bird communities differ along a habitat gradient. Global Ecol Conserv 23:e01150

Hanowski JM, Niemi GJ (1995) Experimental design considerations for establishing an off-road, habitat-specific bird monitoring program using point counts. USDA Forest Service General Technical Report PSW-GTR-149

Hansen SO, Hattendorf J, Wittenberg R, Reznik SY, Nielsen C, Ravn HP, Nentwig W (2006) Phytophagous insects of giant hogweed Heracleum mantegazzianum (Apiaceae) in invaded areas of Europe and its native area of the Caucasus. Eur J Entomol 103:387-395

Hattendorf J, Hansen SO, Nentwig W (2007) Defence systems of Heracleum mantegazzianum. In: Pyšek P, Cock MJW, Nentwig W, Ravn HP (eds) Ecology and management of Giant Hogweed (Heracleum mantegazzianum). CABI, Wallingford, UK, pp 209-225

Hejda M, Hanzelka J, Kadlec T, Štrobl M, Pyšek P, Reif J (2017) Impacts of an invasive tree across trophic levels: species richness, community composition and resident species' traits. Divers Distrib 23:997-1007

Jõgar K, Kuusik A, Metspalu L, Hiiesaar K, Luik A, Grishakova M (2006) Results of treatments with natural insecticidal substances on the development and physiological state of insects. Agron Res 4:203-210

Kim JH (2019) Multicollinearity and misleading statistical results. Korean J Anesthesiol 72(6):558-569. https://doi.org/10.4097/kja.19087

Krištín A (1989) Diet of syntopic species Chiffchaff (Phylloscopus collybita) and Dunnock (Prunella modularis). Folia Zool 38(4):349-362
Krištín A (1990) Diet of Erithacus rubecula and Troglodytes troglodytes nestlings in oak-beech forest. Sylvia 27:79-87

Krištín A, Exnerová A (1994) On the diet and breeding biology of Tree Pipit (Anthus trivialis) and Black Redstart (Phoencurus ochruros). Sylvia 30:64-71

Litt AR, Cord EE, Fulbright TE, Schuster GL (2014) Effects of invasive plants on arthropods. Conserv Biol 28:1532-1549

Lüdecke D, Makowski D, Waggoner P, Patil I (2020) performance: assessment of regression 410 models performance. Available at https:// CRAN.R-project.org/package $=$ performance

Mangachena JR, Geerts S (2017) Invasive alien trees reduce bird species richness and abundance of mutualistic frugivores and nectarivores; a bird's eye view on a conflict of interest species in riparian habitats. Ecol Res 32:667-676

McGowan PJK, Traylor-Holzer K, Leus K (2017) IUCN Guidelines for determining when and how ex situ management should be used in species conservation. Conserv Lett 10:361-366

Moravcová L, Gudžinskas Z, Pyšek P, Pergl J, Perglova I (2007) Seed ecology of Heracleum mantegazzianum and $H$. sosnowskyi, two invasive species with different distributions in Europe. In: Pyšek P, Cock MJW, Nentwig W, Ravn HP (eds) Ecology and management of giant hogweed (Heracleum mantegazzianum). CABI, Wallingford, UK, pp 157-169

Motis A, Estrada J, Oro D (1997) Nestling diet of the spotless starling Sturnus unicolor and the European starling Sturnus vulgaris in a sympatric breeding area. Ornis Fenn 74:179-185

Narango DL, Tallamy DW, Marra PP (2018) Nonnative plants reduce population growth of an insectivorous bird. Proc Natl Acad Sci USA 115(45):11549-11554

Nelson SB, Coon JJ, Duchardt CJ, Fischer JD, Halsey SJ, Kranz AJ, Parker CM, Schneider SC, Swartz TM, Miller JR (2017) Patterns and mechanisms of invasive plant impacts on North American birds: a systematic review. Biol Inv 19:1547-1563

Nicolai B (2001) Feeding of Black Redstart Phoenicurus ochruros at postnuptial migration on Menorca. Anu Ornitol Balear 16:15-22

Oksanen J, Blanchet FG, Friendly M, Kindt R, Legendre P, McGlinn D, Minchin PR, O'Hara RB, Simpson GL, Solymos P, Stevens MHH, Szoecs E, Wagner H (2019) Vegan: community ecology package. R Package Version 2.5-5

Orlov B, Gelashvili D, Ibrahimov A (1990) Poisonous animals and plants of the USSR. Vysshaya Shkola, Moscow

Orłowski G, Karg J (2011) Diet of nestling Barn Swallows Hirundo rustica in rural areas of Poland. Cent Eur J Biol 6(6):1023-1035

Osborne DC, Sparling DW, Hopkins RL II (2012) Influence of conservation reserve program mid-contract management and landscape composition on northern bobwhite in tall fescue monocultures. J Wildl Manag 76:566-574

Perglová I, Pergl J, Pyšek P (2007) Reproductive ecology of Heracleum mantegazzianum . In: Pyšek P, Cock MJW, Nentwig W, Ravn HP (eds) Ecology and management of giant hogweed (Heracleum mantegazzianum). CABI, Wallingford, UK, pp 55-73

Pudil M, Exnerová A (2015) Diet and foraging behaviour of the Whinchat (Saxicola rubetra). In: Bastian H-V, Feulner J (eds) Living on the edge of extinction in Europe. Proc. 1st European Whinchat Symposium. LBV Hof, Helmbrechts, pp 125-134

Pyšek P, Cock MJW, Nentwig W, Ravn HP (2007) Master of all traits: can we succesfully fight giant hogweed. In: Pyšek P, Cock MJW, Nentwig W, Ravn HP (eds) Ecology and management of giant hogweed (Heracleum mantegazzianum). CABI, Wallingford, UK, pp 297-312

R Core Team (2019) R: a language and environment for statistical computing. R Foundation for Statistical Computing, Vienna, Austria. URL https://www.R-project.org/

Reichard SH, Chalker-Scott L, Buchanan S (2001) Interactions among nonnative plants and birds. In: Marzluff JM, Bowman R, Donnelly R (eds) Avian ecology and conservation in an urbanizing world. Kluwer Academic, Norwell, MA, USA, pp 179-223 
Reidy JL, Thompson FR III, Bailey JW (2011) Comparison of methods for estimating density of forest songbirds from point counts. J Wildl Manag 75(3):558-568

Satsyperova IF (1984) Borshcheviki flory SSSR—novye kormovye rasteniya. In: Russian: The genus Heracleum of the flora of the USSR - new fodder plants, Leningrad

Skórka P, Lenda M, Tryjanowski P (2010) Invasive alien goldenrods negatively affect grassland bird communities in Eastern Europe. Biol Conserv 143:856-861

Sliwinski M, Powell L, Koper N, Giovanni M, Schacht W (2016) Research design considerations to ensure detection of all species in an avian community. Methods Ecol Evol 7:456-462

Śliwiński M, Śliwiński M, Anioł-Kwiatkowska J (2011) Rozprzestrzenianie się Heracleum sosnowskyi Manden. i Heracleum mantegazzianum Sommier \& Levier (Apiaceae) w aglomeracji wrocławskiej. Bad Fizjogr R II Ser B Bot 151-163

Štrobl M, Saska P, Seidl M, Kocian M, Tajovský K, Řezáč M, Skuhrovec J, Marhoul P, Zbuzek B, Jakubec P, Knapp M, Kadlec T (2019) Impact of an invasive tree on arthropod assemblages in woodlots isolated within an intensive agricultural landscape. Divers Distrib 25:1800-1813

Ustinova EN, Savina KA, Lysenkov SN (2017) New data on consortive associations of Sosnowsky's hogweed with anthophilous insects. Rus J Biol Inv 8(4):375-385 van Heezik Y, Seddon PJ (2012) Accounting for detectability when estimating avian abundance in an urban area. New Zealand J Ecol 36(3):1-7

Vila M, D'Antonio CM (1998) Fruit choice and seed dispersal of invasive vs. non-invasive Carpobrotus (Aizoaceae) in coastal California. Ecology 79:1053-1060

Walker HA (2008) Floristics and physiognomy determine migrant landbird response to Tamarisk (Tamarix ramosissima) invasion in riparian areas. Auk 125:520-531

Wei T, Simko V (2017). R package "corrplot”: visualization of a correlation matrix (version 0.84). Available from https://github.com/taiyun/ corrplot

Wickham H (2016) ggplot2: elegant graphics for data analysis. SpringerVerlag, New York

Wickham H, François R, Henry L, Müller K (2020) dplyr: a grammar of data manipulation. $\mathrm{R}$ package version 1.0.2

Witmer MC (1996) Annual diet of Cedar Waxwings based on US biological survey records (1885-1950) compared to diet of American Robins: contrasts in dietary patterns and natural history. Auk 113:414-430

Publisher's Note Springer Nature remains neutral with regard to jurisdictional claims in published maps and institutional affiliations. 